\title{
PENGARUH PROSES POST WELD HEAT TREATMENT PADA HASIL PENGELASAN SMAW TERHADAP KETANGGUHAN BAJA KARBON RENDAH
}

\author{
Trio Fazli Ananda \\ Jurusan Teknik Mesin, Fakultas Teknik, Universitas Negeri Padang \\ Kampus Air Tawar, Padang 25131, Indonesia \\ triofazli25@gmail.com
}

\begin{abstract}
Abstrak
Panas yang dihasilkan pada saat proses pengelasan cenderung tidak terdistribusi secara merata antara logam las, logam dasar, daerah HAZ sehingga menghasilkan tegangan sisa. Jadi untuk mendapatkan hasil pengelasan yang seperti diinginkan perlu diberi suatu perlakuan panas untuk menghilangkan tegangan sisa melalui proses post weld heat treatment (PWHT). Tujuan dari penelitian ini adalah untuk mengetahui pengaruh proses post weld heat treatment pada hasil pengelasan SMAW terhadap ketangguhan baja karbon rendah dengan variasi suhu $600^{\circ} \mathrm{C}, 650^{\circ} \mathrm{C}$ dengan waktu penahanan 30 menit yang dipanaskan dalam furnace dan didinginkan di udara bebas. Jenis Penelitian yang dilakukan adalah penelitian eksperimen. Pengelasan menggunakan jenis las SMAW dengan objek penelitian baja karbon rendah ST 42. Hasil dari pengujian impact menunjukan terjadinya peningkatan harga impact pada baja karbon rendah hasil proses pengelasan setelah dilakukan proses post weld heat treatment. Spesimen baja karbon rendah raw material memiliki rata-rata harga impact $\mathbf{1 , 5 8} \times \mathbf{1 0} \mathbf{6} \mathbf{N} / \mathbf{m}$. Spesimen baja karbon rendah tanpa proses annealing memiliki rata-rata harga impact $0,99 \times 10^{6} \mathbf{N} / \mathbf{m}$. Spesimen baja karbon rendah dengan suhu PWHT $600^{\circ} \mathrm{C}$ memiliki rata-rata harga impact $\mathbf{1 , 1 6}$ x $10^{6} \mathrm{~N} / \mathbf{m}$. Spesimen baja karbon rendah dengan suhu PWHT $650^{\circ} \mathrm{C}$ memiliki rata-rata harga impact 1,42 $\times 1 \mathbf{1 0}^{6}$ $\mathbf{N} / \mathbf{m}$. Berdasarkan data pengujian impact yang dilakukan diperoleh gambaran bahwa pada suhu annealing $650^{\circ} \mathrm{C}$ dapat mengembalikan tingkat ketangguhan baja hasil pengelasan menyerupai ketangguhan baja raw material.
\end{abstract}

Kata Kunci : , PWHT, Hasil Pengelasan SMAW, Ketangguhan, Baja karbon rendah

\section{Pendahuluan}

Salah satu perkembangan teknologi yang berkembang pada saat ini adalah bidang kontruksi. Perkembangan teknologi tersebut tidak terlepas dari komponen-komponen yang terbuat dari logam. Hampir pada semua pembangunan suatu kontruksi dengan logam melibatkan unsur pengelasan. Proses pengelasan bukan tujuan utama dari kontruksi melainkan untuk mencapai tujuan ekonomi yang lebih baik, karena itu rancangan las dan prosedur pengelasan harus memperhatikan kesesuaian antara sifat fisis dan mekanis dari logam las (Harsono Wiryosumarto dan Toshie Okumura 2008).

Salah satu pengelasan yang sering digunakan dalam dunia pengelasan adalah shielded metal arc welding atau pengelasan busur listrik elektroda terbungkus. Baja dengan pengelasan SMAW sangat luas penggunaanya karena lebih praktis dan mudah mengoperasikannya, pengelasan SMAW dapat digunakan untuk segala macam posisi pengelasan dan lebih efesien. Pengelasan memunculkan efek pemanasan setempat dengan temperatur tinggi yang menyebabkan logam mengalami ekspansi termal maupun penyusut saat pendinginan. Hal itu menyebabkan terjadinya tegangan-tegangan pada daerah las, tegangan ini disebut tegangan sisa. Tegangan sisa akibat pengelasan dapat memunculkan retak las dan dapat membahayakan kontruksi yang dilas apabila menerima pembebanan.

Untuk membebaskan tegangan sisa ada dua cara, yaitu cara mekanik dan cara termal. Dari kedua cara ini yang paling banyak dilaksanakan adalah cara termal dengan proses annealing atau post weld heat treatment (Harsono Wiryosumarto dan Toshie Okumura 2008). Proses annealing adalah proses pemanasan logam pada suhu tertentu, mempertahankan suhu tersebut pada waktu 
tertentu dan selanjutnya didinginkan secara perlahan. Annealing memiliki banyak fungsi selain menurunkan tegangan sisa, juga meningkatkan ketangguhan di daerah HAZ dan memperbaiki butir-butir kristal suatu material. Besar butir-butir kristal sangat mempengaruhi energi patah dan perambatan retak, makin halus butir-butir kristal maka makin rendah kegetasannya. Dan untuk melihat keuletan dan ketangguhan yang terjadi pada material tersebut dilakukanlah proses uji impact.

\section{Kajian Teori}

\section{A.Baja Karbon}

Baja karbon adalah paduan besi dan karbon dengan sedikit $\mathrm{Si}, \mathrm{Mn}, \mathrm{P}, \mathrm{Cu}$ (Tata Surdia 1995). Menurut komposisinya campuran karbon pada baja ada yang disebut baja karbon rendah (Low Carbon Steel), baja karbon sedang (Medium Carbon Steel), dan karbon tinggi (High Carbon Steel) yang tingkat kekerasannya sebanding dengan kadar karbon tersebut (Jasman 2018). Kadar karbon baja karbon rendah kurang dari $0,25 \%$ serta struktur mikronya terdiri atas ferit dan perlit, sehingga bersifat lunak, tetapi memiliki keuletan dan ketangguhan yang sangat baik (Bondan Tiara Sofyan 2010).

\section{B. Perlakuan Panas (Heat Treatment)}

Perlakuan panas adalah proses pemanasan dan pendinginan pada sebuah baja paduan dengan tujuan untuk mengubah sifat mekanik baja tersebut (Jasman 2014). Ada beberapa jenis perlakuan panas diantaranya hardening, tempering, carburizing, annealing, nitriding dan normalizing. Annealing dapat didefinisikan sebagai pemanasan pada suhu yang sesuai, diikuti dengan pendinginan pada kecepatan yang sesuai (Hari Amanto dan Daryanto 2003).

Annealing adalah proses PWHT (Post Weld Heat Treatment) yang mempunyai tujuan untuk memperbaiki keuletan dan menurunkan tegangan tarik (Yustiasih Purwaningrum 2006).

\section{B. Pengelasan}

Pengelasan (welding) adalah suatu cara untuk menyambung benda padat dengan jalan mencairkan melalui pemanasan (Widharto 2001). Besar arus listrik dalam pengelasan SMAW berpengaruh pada hasil pengelasan (Purwantono 2016). Pengelasan SMAW sering digunakan karena peralatannya murah, portable, sederhana serta mudah. Faktorfaktor yang perlu diperhatikan dalam proses pengelasan adalah proses pengelasan, jenis bahan, besar kecilnya sumber panas, kecepatan pengelasan, komposisi bahan tambah, dimensi dan fungsi benda kerja (Nelvi erizon 2009). Jika juru las terampil dan prosedur pengelasan yang dilakukan sesuai dengan prosedur maka kualitas dari sambungan pasti akan lebih baik (Irzal 2014).

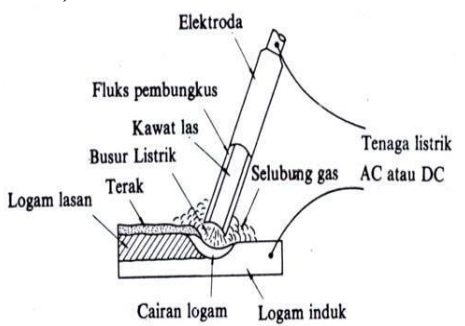

Gambar 1. Las Busur (Sumber : Harsono Wiryosumarto dan Toshie Okumura 2008)

Pada gambar 1 menjelasakan logam induk mengalami pencairan akibat pemanasan dari busur listrik yang timbul antara ujung elektroda dan permukaan benda kerja.

\section{Struktur Mikro Daerah Pengaruh Las}

Daerah pengaruh panas atau Heat Afected zone (HAZ) adalah daerah antara bahan dasar (logam induk tak pengaruh panas) dengan daerah logam las (Nelvi Erizon 2013). Struktur mikro material ada fasa - fasa yang tersusun didalamnya yaitu austenit, ferit, sementit, perlit dan martensit. Fasa austenit terbentuk pada baja ditemperatur tinggi. Jika fasa austenit didinginkan secara lambat maka akan terbentuk fasa ferit dan perlit. Fasa ferit hanya dapat menampung unsur karbon $0,025 \%$ yang bersifat lunak. Fasa sementit tidak seperti ferit dan austenit, sementit merupakan senyawa yang bersifat sangat keras dan mengandung $6,67 \%$ C. Sementit sangat keras tetapi bila bercampur dengan ferit yang lunak maka kekerasannya menurun. Campuran ferit dengan perlit ini disebut perlit.

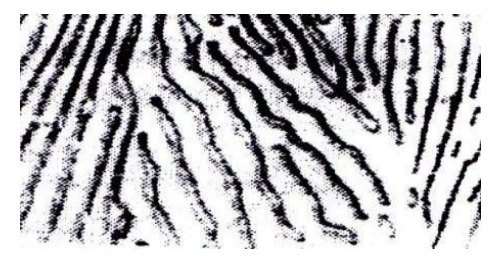

Gambar 2. Struktur Mikro Perlit

(Sumber : Hery Sonawan dan Rochim Suratman 2004) 


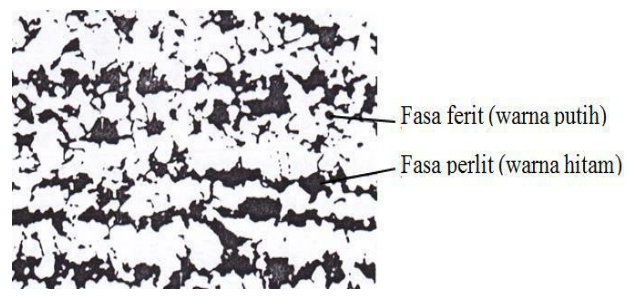

Gambar 3. Struktur Mikro Ferit+Perlit

(Sumber : Hery Sonawan dan Rochim Suratman 2004)

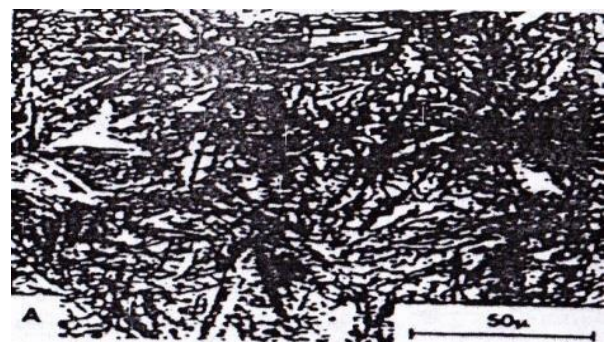

Gambar 4. Struktur Martensit (Sumber

: Hery Sonawan dan Rochim Suratman 2004)

\section{Pengujian Impact}

Pengujian impact merupakan respon terhadap beban kejut atau beban tiba-tiba. Pengujian Impact/ pukul takik akan menghasilkan suatu serapan energy yang digunakan untuk menentukan parameter ketangguhan material (Hendri Nurdin 2016). Impact test are designed to measure theresistance to failure of a material to a suddenly applied force. The test measures the impact energy, or the energy absorbed prior to fracture (Al-Qawabah, dkk 2012). Dalam pengujian ini terdapat dua macam cara pengujian yakni cara Izod dan cara Charpy.

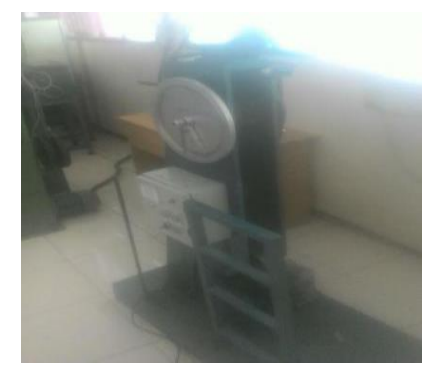

\section{Gambar 5. Gambar Alat Uji Impact Charpy}

\section{Metode Penelitian}

\section{A. Jenis penelitian}

Penelitian ini merupakan penelitian eksperimen. Metode penelitian eksperimen dapat diartikan sebagai metode penelitian yang digunakan untuk mencari pengaruh perlakuan terhadap yang lain dalam kondisi yang terkendalikan (Sugiyono 2012). Penelitian ini bertujuan untuk mengetahui. Pengujian yang dilakukan untuk mengetahui pengaruh proses post weld heat treatment pada hasil pengelasan SMAW terhadap ketangguhan baja karbon rendah sifat dari bahan hasil dari proses annealing yaitu uji Impact dengan menggunakan metode Charpy.

\section{B. Objek Penelitian}

Dalam penelitian ini objek penelitian yang akan digunakan adalah baja karbon rendah ST 42 yang siap di las dan raw spesimen berbentuk lembaran plat (persegi) dengan ukuran $56 \mathrm{~mm} \times 10 \mathrm{~mm} \times 10 \mathrm{~mm}$. Hasil dari pengelasan SMAW kemudian dilakukan proses post weld heat treatment dan dilakukan pengujian Impact. Standar spesimen uji mengacu pada ASTM E8 (ASTM E8/E8 M-11.2001)

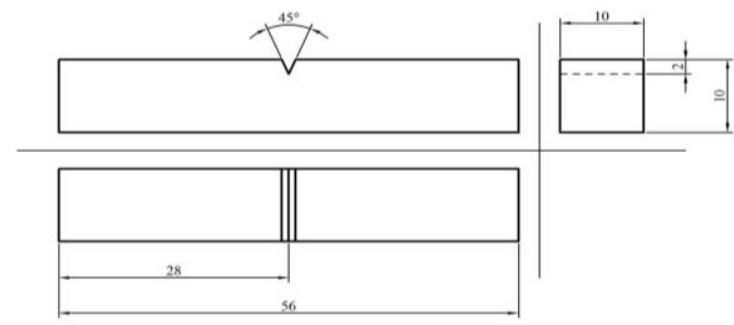

\section{Gambar 6. Spesimen Penelitian}

\section{Teknik Analisis Data}

Metode pengumpulan data dalam penelitian ini adalah dengan metode dokumentasi, observasi eksperimen langsung yaitu metode pengumpulan data penelitian yang dengan sengaja dan secara sistematis mengadakan perlakuan atau tindakan pengamatan terhadap suatu variabel dan eksperimen yaitu mencari hubungan sebab akibat antara dua faktor atau lebih yang sengaja dimunculkan dalam setiap perbukuan. Pengambilan data yang dilakukan adalah dengan meneliti atau mengukur sifat fisis dan mekanis material dengan pengelasan SMAW menggunakan perlakuan panas annealing pada suhu $600^{\circ} \mathrm{C}, 650^{\circ} \mathrm{C}$ pada waktu 30 menit yang kemudian sebagai kelompok eksperimen. Sedangkan kelompok kontrol adalah objek penelitian raw material dan spesimen yang di las tanpa perlakuan proses Post weld heat treatment. 


\section{D.Alat Dan Bahan}

1. Alat

a). Mesin las listrik beserta perlengkapannya

b). Tang dan palu terak

c). Sikat Baja

d). Tang Penjepit

e). Gergaji besi

f). Kikir

g). Jangka sorong ( alat ukur panjang )

h). Bevel protector ( alat ukur sudut)

i). Mesin sekrap beserta perlengkapannya

j). Alat uji ketangguhan impact Charpy.

k). Furnace logam (mesin open logam)

\section{Bahan}

a).Material logam yang digunakan adalah baja karbon rendah ST 42 dengan ukuran 56 $\mathrm{mm} \times 10 \mathrm{~mm} \times 10 \mathrm{~mm}$.

b).Pengelasan yang digunakan adalah pengelasan busur nyala logam terlindung atau SMAW (shielded metal arc welding).

c).Elektroda yang digunakan adalah jenis E6011 standar ASTM (American society for testing material) khusus baja karbon rendah dan arus yang dipakai 78-125 A.

d). Post weld heat treatment yang dipakai adalah pada suhu $600^{\circ} \mathrm{C}, 650^{\circ} \mathrm{C}$ dan waktu penahanan 30 menit

e). Pengujian yang dilakukan adalah uji impact yang dilakukan pada daerah logam las.

\section{E. Prosedur Penelitian}

1. Persiapan Penelitian

Memotong spesimen dengan ukuran 140 $\mathrm{mm} \times 28 \mathrm{~mm} \times 10 \mathrm{~mm}$ sebanyak 2 buah kemudian membentuk Kampu $\mathrm{V}$ dan Raw Material.

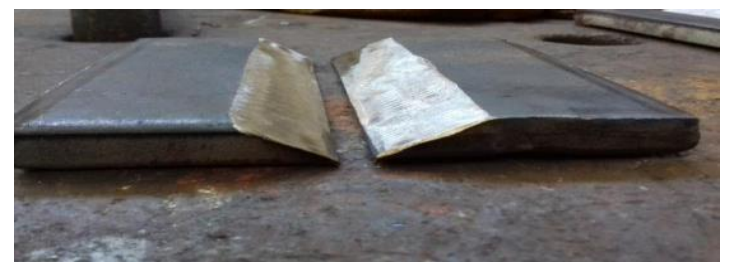

\section{Gambar 7. Pembuatan Kampu V}

\section{Proses Pengelasan}

Jenis las yang digunakan untuk spesimen ini adalah Shielded Metal Arc Welding $(S M A W)$. Karena pengelasan ini mempunyai banyak keuntungan antara lain : praktis, hasilnya dapat diandalkan, effisien, dan ekonomis.

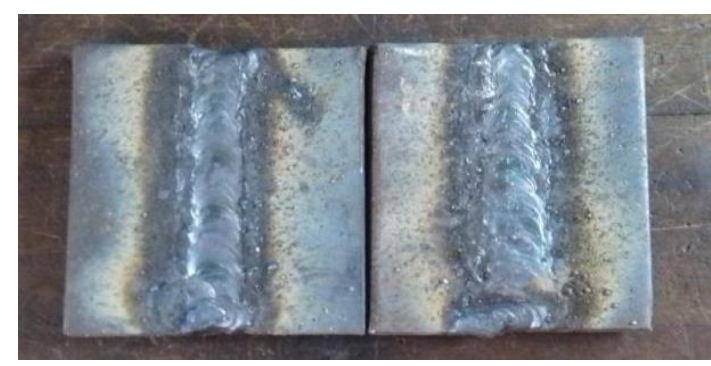

\section{Gambar 8. Hasil Pengelasan SMAW}

3. Proses Pemotongan Spesimen.

Setelah spesimen siap dilakukan proses pengelasan maka spesimen tersebut dibersihkan terlebih dahulu dengan menggunakan mesin skraf kemudian dipotong kembali dengan ukuran $56 \mathrm{~mm} \times 10 \mathrm{~mm} \times 10$ $\mathrm{mm}$ dengan dalam takikan $2 \mathrm{~mm}$.

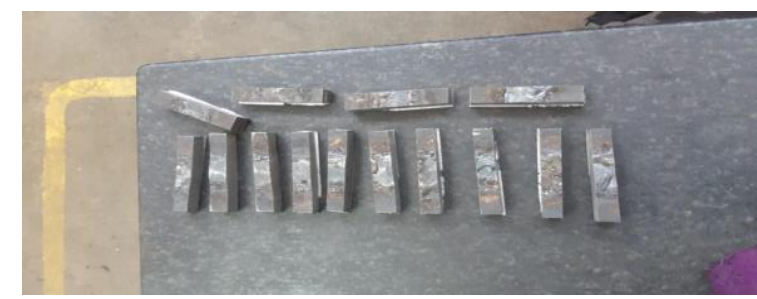

\section{Gambar 9. Hasil Pemotongan Spesimen}

4. Pembagian Spesimen Uji

a) Spesimen A sebanyak 3 Spesimen yaitu spesimen Raw Marerial dan dilakukan pengujian impact.

b) Spesimen B sebanyak 3 Spesimen yaitu spesimen yang di las dan tidak dilakukan proses post weld heat treatment dan dilakukan pengujian impact.

c) Spesimen C sebanyak 3 Spesimen yaitu spesimen dengan suhu post weld heat treatment $600^{\circ} \mathrm{C}$ dan ditahan selama 30 Menit kemudian didinginkan secara perlahan.

d) Spesimen D sebanyak 3 Spesimen yaitu spesimen dengan suhu post weld heat treatment $650^{\circ} \mathrm{C}$ dan ditahan selama 30 Menit kemudian didinginkan secara perlahan.

\section{Proses Pemanasan}

Proses pemanasan baja dilakukan dalam oven dengan variasi suhu antara $600^{\circ} \mathrm{C}$, $650^{\circ} \mathrm{C}$ selama 30 Menit. Kemudian spesimen didinginkan secara perlahan diudara supaya dinginnya berlangsung secara perlahan-lahan. 


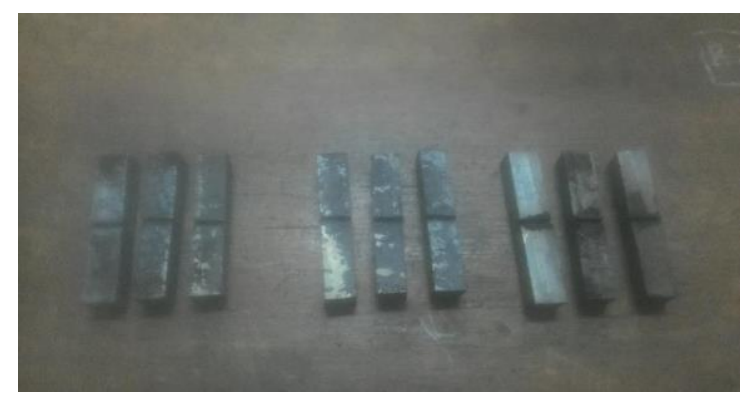

\section{Gambar 10. Hasil Proses Annealing}

\section{Pengujian Impact}

Pengujian Impact pada spesimen dapat dilakukan dengan langkah-langkah sebagai berikut :

a) Siapkan peralatan dan mesin uji impact ( Impact Chapy)

b) Mengkondisikan mesin penguji dalam kondisi standar yaitu dengan melakukan kalibrasi sesuai dengan ukuran standar.

c) Spesimen yang sudah dibersihkan diletakkan pada mesin uji impact

d) Setelah spesimen uji dijepit, kemudian tarik bandul pada mesin uji kemudian lepaskan. Dilepaskan dengan menarik pengunci lengan, maka bandul akan berayun mematahkan benda uji.

e) Perhatikan ukuran yang ada pada skala mesin uji kemudian dicatat.

f) Lakukan analisa pada setiap data pengujian yang dihasilkan.

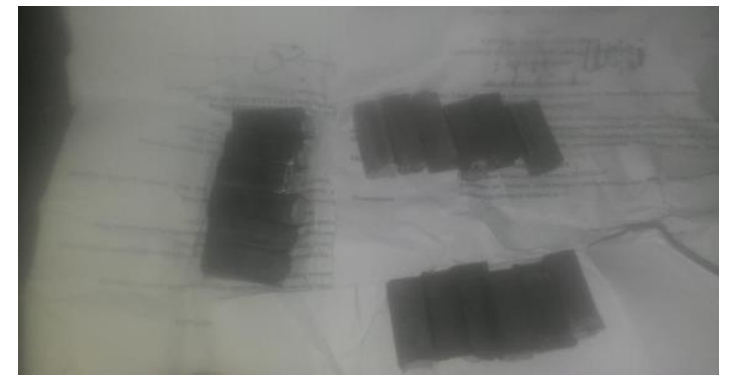

\section{Gambar 12. Hasil Pengujian Impact}

\section{Hasil Pembahasan}

\section{A. Data Hasil Penelitian}

Pengujian impact telah di lakukan dengan menggunakan impact testing machine terhadap seluruh spesimen ST 42 yang diberi perlakuan annealing dengan variasi suhu pemanasan. Hasilnya dapat dilihat pada tabel 1 di bawah ini.
Tabel 1 Daftar Harga Impact

\begin{tabular}{|l|l|l|l|}
\hline No & Specimen & $\mathbf{E}$ & HI \\
\hline $\mathbf{1}$ & $\begin{array}{l}\text { Raw } \\
\text { Material }\end{array}$ & 126,24 & 1,57 \\
\hline & & 129,32 & 1,61 \\
\hline & & 126,24 & 1,57 \\
\hline & & & $\mathbf{1 , 5 8}$ \\
\hline $\mathbf{2}$ & Hasil las & 78,91 & 0,98 \\
\hline & & 78,91 & 0,98 \\
\hline & & 81,84 & 1,02 \\
\hline & & & $\mathbf{0 , 9 9}$ \\
\hline $\mathbf{3 .}$ & Suhu 600 C & 87,71 & 1,09 \\
\hline & & 99,45 & 1,24 \\
\hline & & 93,58 & 1,16 \\
\hline & & & $\mathbf{1 , 1 6}$ \\
\hline $\mathbf{4 .}$ & Suhu 650 C & 111,37 & 1,39 \\
\hline & & 117,24 & 1,46 \\
\hline & & 114,30 & 1,42 \\
\hline & & & $\mathbf{1 , 4 2}$ \\
\hline
\end{tabular}

\section{B. Pembahasan}

Dengan adanya perlakuan panas post weld heat diharapkan dapat membuat struktur butiran disemua daerah lebih seragam dan keuletannya meningkat sehingga dapat diperoleh kesamaan sifat mekanik hasil pengelasan SMAW.

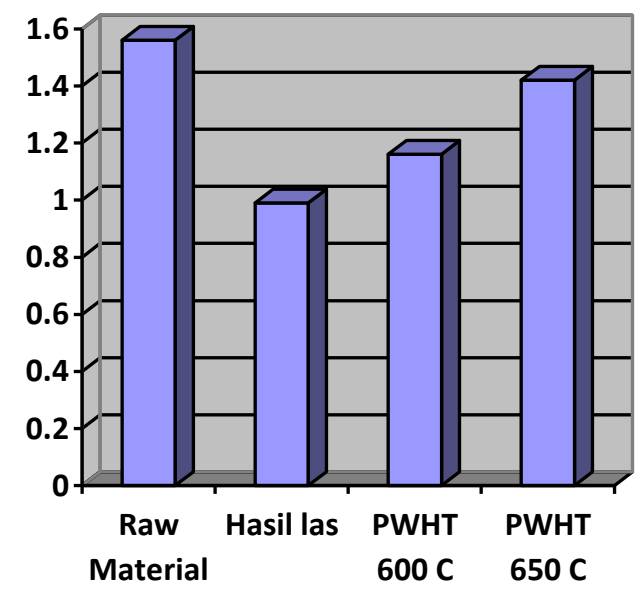

\section{Gambar 12. Grafik Pengujian Impact.}

Pada grafik diatas harga Impact baja ST 42 paling tinggi dicapai sebesar 1,42 x $10^{6}$ $\mathrm{N} / \mathrm{m}$ dan yang terendah $0,99 \times 10^{6} \mathrm{~N} / \mathrm{m}$, sedangkan pada baja raw material $1,56 \times 10^{6}$ $\mathrm{N} / \mathrm{m}$. Hal ini membuktikan bahwa variasi 
temperature yang digunakan berpengaruh terhadap harga impact proses post weld heat treatment. Harga impact turun tajam ketika terjadinya proses pengelasan tanpa perlakuan post weld heat. Hal ini menunjukan bahwa proses post weld heat pada baja hingga temperatur $650^{\circ} \mathrm{C}$ dapat mengembalikan ketangguhan baja menyerupai baja raw material.

\section{Kesimpulan}

Berdasarkan hasil penelitian dan analisa dalam penelitian ini dapat disimpulkan sebagai berikut:

1. Adanya proses variasi suhu post weld heat menyebabkan naiknya ketangguhan pada baja ST 42 ditandai dengan naiknya harga impact.

2. Hubungan dari rata-rata setiap harga impact berbanding dengan transisi temperatur, susuai dengan pengujian yang telah peneliti lakukan, di dapat rata-rata harga impact dari temperatur $600^{\circ} \mathrm{C}$ sebesar $1,16 \times 10^{6} \mathrm{~N} / \mathrm{m}$, temperatur $650^{\circ} \mathrm{C}$ sebesar $1,42 \times 10^{6}$ $\mathrm{N} / \mathrm{m}$.

3. Dalam proses annealing semakin tinggi suhu yang digunakan menyebabkan nilai ketangguhan semakin tinggi pula sehingga dapat menyerupai ketangguhan material dasar (Raw Material).

\section{Referensi}

Al-Qawabah, S.M.A, Nabeel Alshabatat dan U.F. Al-Qawabeha. (2012). Effect of Annealing Temperature on the Microstructure, Microhardness, Mecha nical Behavior and Impact

Toughness of Low Carbon Steel Grade 45.Jurnal IJERA. Vol 2. No. 3. Hal: 1550-1553.

ASTM, E8/E8 M-11 . (2012). Standar test methods for tension testing of metalic..Material. USA.

Bondan Tiara Sofyan. (2010). Pengantar Material Teknik. Jakarta: Salemba Teknika.

Hari Amanto Daryanto. (2013). Ilmu Bahan. Jakarta: Bumi Aksara
Harsono Wiryosumarto, Toshie Okumura. (2008). Teknologi Pengelasan Logam. Jakarta: Pratya Pramita.

Hendi Nurdin. (2016). Praktikum Pengujian Bahan. Jurusan Teknik. Universitas Negeri Padang.

Hery Sonawan dan Rochim Suratman.

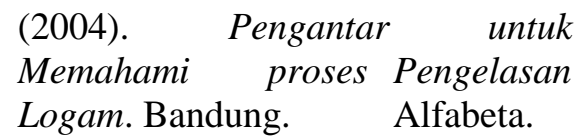

Irzal (2014).Analisis kekuatan tarik sambungan las pada pipa baja karbon menggunakan elektroda E7018 dengan posisi pengelasan 5G. http://jurnal.upi.edu/proccedingfptk /e

Jasman, J dan Risno Fendri. (2018). Analisis Sifat Mekanik dan Struktur Mikro Baja AISI 4041 Akibat Perbedaan Temperatur pada Perlakuan Panas Tempering. Universitas Negeri Padang. Teknomekanik.1 pp. 37-47.

J Jasman, I Irzal, J Adri, P Pebrian. (2018). Effect of Strong Welding Flow on the Violence of Low Carbon Steel Results of SMAW Welding with Electrodes 7018. Teknomekanik. 1 (1), 24-31

Muhammad Alip. (1989). Teori dan Praktek las. Jakarta : Dapertemen pendidikan dan kebudayaan.

Nelvi Erizon. (2009). Pengaruh panas pengelasan pada baja karbon rendah terhadap fisis dan mekanis. IVOTEK. Vol X. Hal: 2359-2381.

Nelvi Erizon .(2013). Pengaruh Kecepatan Pengelasan Pada Baja Karbon Rendah Terhadap Kualitas Hasil Las Pada Pengelasan Las Busur Listrik. A-05-013 . Hal: 1 - 19

Purwantono dan Despa Wandri. (2016). Pengaruh arus ac dan $d c$ terhadap hasil pengelasan pad alas busur listrik. Jurnal Teknik Mesin, Universitas Negeri Padang. Hal: 1-7.

Sugiyono. (2012). Metode Penelitian kuantitatif, kualitatif dan $R \& D$. Bandung: ALFABETA . 
Tata Surdia. (1995). Pengetahuan Bahan Teknik. Jakarta. PT Pradnya Paramita.

Widharto. (2001). Petunjuk Kerja Las. Jakarta: PT. Pradnya

Yustiasih Purwaningrum. (2006).

Karakterisasi Sifat Fisis dan

Mekanis sambungan Las

SMAW Baja A-287 Sebelum dan

Sesudah PWHT. Jurnal TEKNOIN.

Vol. 11, No. 3. Hal: $\quad$ 233-242. 